\title{
Classes Duo Paris/Knoxville, an Integrative Learning Experience: A Case Study
}

\author{
Monique Y. Wells \\ Wells International Foundation, Paris, France \\ Kathleen Stein-Smith \\ Fairleigh Dickinson University, Metropolitan Campus, Teaneck, NJ, USA
}

\begin{abstract}
This case study examines the role of integration of the arts into learning within the framework of interdisciplinarity and integrative learning. Specifically, it describes and discusses the Classes Duo Paris/Knoxville program, which brings together students from Paris and Knoxville through the life and art of Knoxville-born, Paris-expatriate artist Beauford Delaney. The integration of the arts, languages (French and English), and travel abroad is the basis for a survey distributed to the adult participants in the program by the organizer, who is one of the authors of this study. Responses to the survey have been described and discussed in terms of arts education and international experiential learning, with implications for similar future initiatives and the current and potential role of philanthropy in educational programming.
\end{abstract}

Index Terms-Beauford Delaney, Wells International Foundation, arts education, bilingual education

\section{INTRODUCTION}

"'Who was Beauford Delaney?' people ask. Those who knew him all say he was a joy to be with, that he loved life -food, wine, sun, and especially light.

The art world is now recognizing him as a major African-American and American painter -- one of the great modernists."

Amazing Grace: A Life of Beauford Delaney, xii (Leeming, 1998)

Language and art are quintessentially human (Hogenboom, 2015), and Paris has been an inspiration and destination for artists for centuries. The Classes Duo program brings together language and art for a group of French and U.S. elementary school students (from Paris and Knoxville, Tennessee, respectively) through the work of Beauford Delaney, a Knoxville-born artist who made his home in Paris for decades in the second half of the 20th century.

In addition to learning about the recognition of Beauford Delaney in his adopted home, the Knoxville students use the medium of art and the medium of the French language to interact with their French student peers and to create their own art.

A visit to Paris by the Knoxville students and their parents in October 2018 is one of the high points of the program. Built on collaborations among education professionals online and through social media, it includes an art exhibit of the Delaney-inspired student artwork at the Knoxville Museum of Art (WIF, 2019). Plans for a reciprocal visit to Knoxville by the French students and their parents are being discussed.

\section{INTERDISCIPLINARITY AND INTEGRATIVE LEARNING}

Interdisciplinarity and integrative learning present opportunities to discover the significance of diversity in effectively addressing the complex questions that society is confronting today. As globalization makes the world and its challenges more complicated, these disciplines provide separate, yet complementary ways to develop an understanding of broad, multidimensional issues, as well as different perspectives and methods of effectively addressing and potentially resolving them. This results in the making of a better world (Newell, 2010). While not necessarily a new idea, interdisciplinarity is often linked with the process and challenges of addressing complex global issues (Augsburg, 2006).

Classes Duo supports integrative learning through its focus on 1) intercultural communication, 2) experiential learning, including creating works of art using different media and interacting in French and English with peers in Paris, and 3) study abroad, through the U.S. students' visit to Paris to meet their French peers. The combination of these elements empowers students to develop an understanding of different perspectives and worldviews through an interdisciplinary approach combining art, history, and language learning. Bringing students together across cultures and languages, the Classes Duo program emphasizes the role that diversity plays in developing creativity and innovation.

Classes Duo provides an opportunity for elementary school students to develop the 4Cs (Critical Thinking, Communication, Collaboration, and Creativity) (Partnership, n.d.) - qualities that are considered essential for students 
to succeed in school and the workplace today. It creates an environment where cultural, linguistic, and disciplinary diversity nurture the students' capacity for creativity, innovation, and problem-solving. Along with the 4Cs, innovation and problem-solving are important for success in today's world (Livermore, 2016; Florida, 2008).

Languages are inherently interdisciplinary (Eger, 2015), reflecting the scope of human experience. As such, they can be viewed as a means of communication and expression rather than an isolated skill. They are also an expression of our cultural identity.

Additionally, language is a means to develop an understanding of another culture. Through Classes Duo, the Knoxville students are learning to speak French to communicate, to build relationships, and to collaborate artistically. This opens a window, not only onto France and the greater Francophone world, but also to the humanist values promoted by the language (OIF, n.d.).

In educational terms, the difference between studying another language as a subject in school and using language as a medium of instruction, communication, learning, and research as part of an immersion experience is significant. Both immersion and learning by doing have a tradition in terms of foreign language learning.

Learning by doing is not a new idea and there are many opportunities to learn another language through cooking, dance, music, and art (Clayton, 1998). However, Classes Duo is more than kinesthetic or tactile learning. As the students interact across cultures, both face to face and online, their interpersonal experience is used to reinforce verbal and communicative learning.

This combination of intercultural communication through language, arts education through artistic self-expression and art appreciation, learning about a famous artist, and seeing how a local artist is honored beyond our borders, is unique (Stein-Smith, 2018).

\section{WHY BEAUFORD DELANEY?}

Whether they embraced expatriate life to escape racism or homophobia, or simply to experience the French art de vivre, many American artists have chosen France, and Paris, as their home (Rickman, 2018). Along with famous U.S. citizens such as Josephine Baker, James Baldwin, Ernest Hemingway, and more recently, Johnny Depp, Beauford Delaney is an example of the significance and tradition of the expatriate artist in the City of Light. Delaney, whose "paintings possess a personal spontaneity that distinguishes him as one of the foremost abstract expressionists of his generation," lived in Paris from 1953 until his death in 1979 (SAAM, n.d.). Born in Knoxville, Tennessee, he is a part not only of his birthplace and the French capital, but also of New York City, where he and his brother, fellow artist Joseph Delaney, lived for a time (Stevens-Garmon, 2019).

\section{Classes Duo: An Interdisciplinary, Intercultural, Multilingual, AND ExPERIENTIAL ARTs LEARning EXPERIENCE}

The Classes Duo program is a wonderful example of what can be accomplished through collaboration - on this occasion, between the U.S. non-profit Wells International Foundation (WIF) and the City of Paris, and between Nature's Way Montessori School in Knoxville, Tennessee and Jean Zay Elementary School in Paris, France (American Elementary School Kids, 2018). Stemming from WIF's successful exhibition of over 40 paintings and works on paper by Beauford Delaney in Paris in 2016 and the involvement and support of this organization, students at both schools have been able to engage in social interaction to develop intercultural understanding and to create and share their own art inspired by Delaney's work (Les Amis, 2017).

Classes Duo is an extra-curricular international exchange program intended to awaken interest in other languages and cultures and to give French elementary school students the opportunity to interact with peers in other countries. Learning goals, objectives, and methodologies are developed collaboratively by the educators in partnering schools, and technology is used to maximize the exchange experience. Communication between the students - using both languages - complements language learning that is already taking place in the classroom.

The Paris/Knoxville iteration of Classes Duo presents an important and unique model for education from multiple perspectives. It contributes positively to the ongoing public conversation on the role and significance of the humanities and the evolution of the emphasis on STEM to STEAM and STEAM'D in education (STEM to STEAM, n.d.; STEAM not STEM, n.d.). It is a vanguard for the advancement of intercultural and bilingual education, which is known for enhancing attention, empathy, tolerance, cross-cultural understanding, and academic performance (Kamenetz, 2016; Thompson, 2016). It also highlights the importance of the arts and art education for today's youth in terms of creativity and cognitive growth (Maslyk, 2016; Sousa \& Pilecki, 2018).

In recent years, art and foreign language programs in U.S. schools have suffered cuts and even elimination for a variety of reasons, including an emphasis on high-stakes testing and budgetary challenges. Many elementary schools no longer have art or foreign language specialists (Americans for the Arts, n.d.; AMACAD, 2017).

The benefits of art education are numerous. In the U.S., a student who is involved in the arts is four times more likely to be recognized for academic achievement. Low-income students who are involved in the arts are more likely to stay in school, to graduate college, to be gainfully employed, and to volunteer in their community than those who are not. In addition, $72 \%$ of business leaders affirm that creativity is the most sought-after skill in hiring. Yet $66 \%$ of 
teachers say that the arts are among areas being crowded out of the curriculum. Many students do not have the opportunity to experience these disciplines as music, visual arts, dance, and theater are far from universally available in elementary and secondary schools, and African-American students have far less access than their white peers (Americans for the Arts, n.d.).

Language is often considered the core of the liberal arts. It is common knowledge that foreign language skills bring personal and professional benefits, but fewer than $20 \%$ of U.S. K-12 students study another language, and many children do not have access to foreign language learning in the early grades (American Councils, 2017; AMACAD, 2017). International education, whose primary goals are "furthering knowledge and cultural capital, learning about places and cultures, and gaining intercultural skills in the process" (Quain, 2018) is another element to consider in reflecting on the Classes Duo initiative.

Within the frameworks of arts education, interdisciplinary and integrative learning, language/bilingual education, and international education, Classes Duo demonstrates both the power of the arts and language in developing appreciation of other cultures and intercultural understanding.

Reflecting the inherent interdisciplinarity of language and communication, the Classes Duo Paris/Knoxville program includes art (oil and watercolor painting, sculpture), writing/literacy (emails and letters exchanged by the students at both schools), foreign language (video introductions and questions delivered by students in the language of the partner class), and technology (monthly video conferencing).

Additionally, the opportunity that the Knoxville children had in October 2018 to visit Paris, to meet the students with whom they have been interacting for nearly a year, and to spend a night with their host families, has taken the learning experience to an entirely different level and provided the recognition that is so important in fostering engagement and achievement. For many of the children, this was their first trip abroad.

It is interesting to reflect on the inspiration for this program - the life and work of Knoxville-born artist Beauford Delaney, who made Paris his home for decades. The Knoxville students had the opportunity to see the neighborhood where Delaney lived in Paris, to visit the Pompidou Center museum, which has a Delaney painting in its collection, and to visit a gallery where they saw several of the artist's works.

In addition to offering a once-in-a lifetime learning experience for these students, enabling them to develop artistic, communicative, and cultural skills through the lens of the life and art of Beauford Delaney, Classes Duo Paris/Knoxville also highlights the relative advantage of STEAM education (science, technology, engineering, the arts, and math) and the role of the arts in addressing ethical and moral issues, in developing empathy, and in recognizing and examining complex social and global questions. As an example, the program has enabled the students on both sides of the Atlantic to explore the subject of racism and civil rights in the U.S. through art, science, and technology.

This empowerment of students through intercultural and interdisciplinary learning is a key underlying theme of the Classes Duo program, which makes it a wonderful experience for the students currently involved as well as a model for other organizations and institutions desirous of developing core values and a mindset of global citizenship from an early age.

Empowerment through Classes Duo includes, but is not limited to, artistic expression, linguistic skills, and cultural knowledge. The participating students' development in all these areas is assisted by technology, facilitated by dedicated teachers and stakeholders, and supported by families and communities in both cities.

The Classes Duo Paris/Knoxville program is framed by and grounded in the core values and focus areas of WIF and the Modern Language Association (MLA).

WIF's mission is "to empower women and persons of African descent to realize their highest potential through arts, literacy, study abroad, and other educational and cultural programs" to build "a network of global citizens who embrace inclusiveness and foster a spirit of cooperation throughout the world." To achieve this goal, the organization "provides and supports a number of multifaceted programs, with activities and projects that target the following Strategic Focus Areas: Women's Empowerment; Literacy; STEAM; Travel and Study Abroad; the Arts; and Training in Preclinical Safety Issues"(WIF, n.d.).

In its landmark report, Foreign Languages and Higher Education: New Structures for a Changed World, MLA defines translingual and transcultural competence as the goals of foreign language learning, highlighting the importance of both interdisciplinarity and K-16 collaborations (MLA, 2007).

The Classes Duo Paris/Knoxville program encompasses the goals of both organizations and ensures that language learning is woven into the education experience it offers. Opportunities to develop transcultural competence have been part of the written and video communications between the two classes and were the principal focus of the visit to Paris by the Knoxville students to meet and spend time with their online Parisian classmates.

Similar programs can be developed using the arts as their springboard on even the smallest budget. Replication possibilities include numerous potential partnerships among communities, schools, institutions of higher learning, cultural organizations, and educators across disciplines.

\section{The Case Study: Methodology And SuRvey Results}

The nature of the Classes Duo experience, the research questions, and the goals of the study caused the researchers/authors to select a qualitative methodology to explore the impact of the Classes Duo experience on the 
students, parents, and educators involved. Case study methodology was determined to be the best suited to the goals of the study (Yin, 2017; Creswell \& Creswell, 2018).

To examine the central research question "How is the Classes Duo experience impacting the participants?", a survey was developed by the authors and distributed to the adult participants by the Classes Duo organizer. Questions were designed to explore and describe how the Classes Duo experience impacted the participants and whether it had been truly transformational, resulting in an embrace of the possibility of new artistic, cultural, and international learning and experiences beyond what may have existed before.

Of the 12 surveys distributed to the adult participants, 11 were returned, 10 from parents and one from an educator, with positive results both from the multiple-choice questions and the answers to an open-ended question on the personal and professional impact of the experience. The 11 multiple-choice questions were qualitative in nature, and the openended question 12 was intended to elicit addition qualitative data left uncovered by the questions. Both parents (10 respondants) and the classroom teacher cited the positive impact of the experience and it open-ended impact in terms of potential learning and travel.

In addition to the positive and enthusiastic comments on the Classes Duo program, it is interesting to note that new friendships, the development of better understanding and appreciation of another culture, as well as the impact of an artist who lived both cultures were the predominant themes. Other reactions voiced included the joy of experiencing international travel with one's child, as well as the wish to travel and even to live abroad.

The survey questions and the survey results can be reviewed in Appendices A, B, C, and D.

\section{Conclusions: Making the World a Better Place; The Role of Philanthropy}

Philanthropy has been defined as "goodwill to fellow members of the human race especially: active effort to promote human welfare" (Merriam-Webster, n.d.) with the goal of making the world a better place. It is this goal that transcends the specifics of any given activity and causes philanthropy to differ from charity. In 2018 , Americans gave \$410.02B to charity, with increases in virtually all areas, including education, arts, humanities, and culture (Giving USA 2018, 2018), predicted to continue for years to come (Callahan, 2017).

WIF's philanthropic mission is to cultivate global citizenship through education and culture. To accomplish this, the foundation creates and implements programs and projects in several Strategic Focus Areas, including the arts, STEAM education, literacy, and travel/study abroad.

It is within the framework of WIF's mission and Strategic Focus Areas that Classes Duo Knoxville/Paris came into being. While the specifics of learning about and creating art, of learning French, and of travelling to Paris are wonderful educational opportunities, the transformational effect of the entire experience on the lives of the students and other participants is what differentiates Classes Duo from a traditional academic program. The overall impact of increasing self-esteem through the development of new artistic and linguistic skills, opening new perspectives through travel abroad and museum visits, and facilitating new conversations and shared interests between parents and children has changed the lives of participating students and educators.

On a broader scale, the program has the potential to change the lives of each person with whom the students and educators may come into contact.

The role of the artistic work and life of Beauford Delaney as the underpinning of the success of the Classes Duo Paris/Knoxville learning experience in the classroom, enhanced by technology and complemented by travel and inperson contact, should not be underestimated. Delaney's legacy is the catalyst that serves to enrich of the lives of the parents and educators, and most importantly, of the children in the program who have created and studied art and worked collaboratively with their peers in another culture.

Beyond the children, families, and educators involved in the Paris/Knoxville program, the Classes Duo model can be replicated to varying degrees in other educational settings in relation to the funding and skills set available.

Based on both the intent of the organizers and the positive experience of students, parents, and educators, more experiences of this type are sorely needed, as is support for arts education, integrative and experiential learning, the importance of an early start to foreign language and intercultural learning, and international education through bilingual education/immersion, as well as travel/study abroad.

Classes Duo confirms the importance of interdisciplinarity - research and learning across disciplines. Art, language and cultural learning have been combined in this program to foster development of the 4C's of Critical Thinking, Communication, Collaboration, and Creativity, all of which are crucial for the students' success in the $21^{\text {st }}$ century. Additionally, Classes Duo is a wonderfully expressive example of how diversity positively influences the development of student problem solving, innovation, and creativity.

\section{ApPendix A. The Survey Instrument: Classes Duo Survey Questions}

QUESTION 1: The Classes Duo experience has increased my understanding of France and French culture.
1. Yes
2. No
3. Not sure 
QUESTION 2: The Classes Duo experience has increased my interest in and appreciation of art.
1. Yes
2. No
3. Not sure

QUESTION 3: The Classes Duo experience has increased my interest in learning more about other cultures and languages.

1. Yes

2. No

3. Not sure

QUESTION 4: The Classes Duo experience has increased my interest in continuing my education and in encouraging my family to do the same.

1. Yes

2. No

3. Not sure

QUESTION 5: The Classes Duo experience has increased my interest in living and/or studying abroad.

1. Yes

2. No

3. Not sure

QUESTION 6: The Classes Duo experience has increased my interest in educational exchanges bringing students from other countries to my community.

1. Yes

2. No

3. Not sure

QUESTION 7: The Classes Duo experience has increased my interest in learning more about artists from my community.

1. Yes

2. No

3. Not sure

QUESTION 8: The Classes Duo experience has increased my interest in international education.
1. Yes
2. No
3. Not sure

QUESTION 9: The Classes Duo experiences has increased my perception of multilingualism as part of intercultural understanding and global citizenship.

1. Yes

2. No

3. Not sure

QUESTION 10: The Classes Duo experience has increased my interest in getting involved in community activities.

1. Yes

2. No

3. Not sure

QUESTION 11: The Classes Duo experience has led me to learn something about arts, cultural, and crossing cultures that I was not aware of before

1. Yes

2. No

3. Not sure

Please describe and discuss the impact of the Classes Duo Knoxville to Paris on the participants and on yourself personally and/or professionally.

\section{APPENDix B. Classes Duo Survey Questions: Responses}

(11 Surveys Returned Out Of 12 Distributed)

QUESTION 1: The Classes Duo experience has increased my understanding of France and French culture.
4. Yes
5. No
6. Not sure

Responses -- 11 Yes

QUESTION 2: The Classes Duo experience has increased my interest in and appreciation of art.
4. Yes
5. No
6. Not sure 
Responses -- 11 Yes

QUESTION 3: The Classes Duo experience has increased my interest in learning more about other cultures and languages.
4. Yes
5. No
6. Not sure

Responses -- 9 Yes; 2 Not sure

QUESTION 4: The Classes Duo experience has increased my interest in continuing my education and in encouraging my family to do the same.
4. Yes
5. No
6. Not sure

Responses -- 7 Yes; 4 Not sure

QUESTION 5: The Classes Duo experience has increased my interest in living and/or studying abroad.
4. Yes
5. No
6. Not sure

Responses -- 8 Yes; 1 No; 2 Not Sure

QUESTION 6: The Classes Duo experience has increased my interest in educational exchanges bringing students from other countries to my community.
4. Yes
5. No
6. Not sure

Responses -- 11 Yes

QUESTION 7: The Classes Duo experience has increased my interest in learning more about artists from my community.
4. Yes
5. No
6. Not sure

Responses -- 8 Yes; 1 No; 2 Not sure

QUESTION 8: The Classes Duo experience has increased my interest in international education.

4. Yes

5. No

6. Not sure

Responses -- 11 Yes

QUESTION 9: The Classes Duo experiences has increased my perception of multilingualism as part of intercultural understanding and global citizenship.
4. Yes
5. No
6. Not sure

Responses -- 9 Yes; 2 Not sure

QUESTION 10: The Classes Duo experience has increased my interest in getting involved in community activities.
4. Yes
5. No
6. Not sure

Responses -- 6 Yes; 5 Not sure

QUESTION 11: The Classes Duo experience has led me to learn something about arts, cultural, and crossing cultures that I was not aware of before
4. Yes
5. No
6. Not sure

Responses -- 10 Yes; 1 No 
ApPendix C. Classes Duo Survey Questions: Results of The Survey Questions 1-11

\begin{tabular}{|c|c|c|c|}
\hline & YES & NO & NOT SURE \\
\hline QUESTION 1 & 11 & & 2 \\
\hline QUESTION 2 & 11 & & 4 \\
\hline QUESTION 3 & 9 & & 2 \\
\hline QUESTION 4 & 7 & & 2 \\
\hline QUESTION 5 & 8 & & 2 \\
\hline QUESTION 6 & 11 & & 5 \\
\hline QUESTION 7 & 8 & & 17 \\
\hline QUESTION 8 & 11 & & \\
\hline QUESTION 9 & 9 & 1 & \\
\hline QUESTION 10 & 6 & 3 & \\
\hline TUESTION 11 & 10 & & \\
\hline
\end{tabular}

QUESTION 12: Please describe and discuss the impact of the Classes Duo Knoxville to Paris on the participants and on yourself personally and/or professionally. It is important to note that this qualitative data was the final survey question, and not in response to any of the previous questions.

\title{
APPENDIX D. RESPONSES TRANSCRIBED
}

\author{
( $\mathrm{xxx}=$ Removed To Ensure Privacy) \\ (10 Responses; 1 Left Blank)
}

\section{PARENT RESPONSES}

My son has an increased appreciation of art and the history associated with art. He enjoys traveling and experiencing other cultures and cuisines. I enjoy having the opportunities like Classes Duo in order to provide him with these experiences and to be able to travel with him.

This has been a phenomenal experience. I'm an art history professor at $\mathbf{x x x}$ and am writing a book on Delaney, so this program essentially folds my family into my professional research and interests. My son and I spend every July in Paris so I can teach a study abroad class, but Classes Duo has managed to deepen his international interests and friendships.

Incredibly positive experience for myself and for my son. Studying Beauford Delaney and his impact on other artists, and art in general, has imbued a greater sense of pride in my own community. Challenging my rudimentary French to get myself through the Metro, through museums, and into new friendships was a growth experience, as travel always is. Seeing the children embrace one another so quickly proved the power of connection. I am very anxious to continue working on more exchanges and continuing to tend the new relationships \& language that we have gained.

The nuclear value of this program is priceless. American students coming together with French students through art, visiting Paris, learning about an artist that is local to us and Paris. Every component of this program is just amazing. We have left with many new friendships and more understanding than before of the education and lifestyle abroad. We loved every moment of it.

Getting to meet $\&$ look into the lives of others from other countries gave me a greater appreciation of our different cultures. The preconceptions I had of France were wrong. I was nervous to be in the city but once I got there felt at ease $\&$ felt treated very fairly a\& well. I think my family \& I will definitely travel abroad again \& may even consider living abroad in a few years.

This program has been life changing for me and the student participants. This program has broadened my world and increased my desire to travel abroad.

My daughter, $\mathbf{x x x}$, now has a very personal connection and affinity toward France and the culture including the art that is so tied to that culture. She has developed a deep respect for Beauford Delaney and his contribution to the U.S. and France and the world through his artwork and his relationships with other artists, writers, and creatives. Our family has enjoyed watching the program grow and being a part of it. Our trip to Paris was spectacular made increasingly more special due to the Classes Duo program. Hoping to continue the international relationships we have gained. I hope to be professionally involved in future overseas study abroad programs. This program has reignited my love of France and travel and my international curiosity.

The impact of the trip was very positive. I learned a lot about the artist Beauford Delany. I learned a lot of French history and enjoyed all of the sites. $\mathrm{i}$ believe it was very educational for my daughter as well. We hope to participate in another trip is the school has it again.

Classes Duo has been a very enlightening experience for me. I have learned so much about Beauford Delaney (I hadn't even heard of him prior to Classes Duo!), the city of Paris, and French language and culture. I know the same can be said on behalf of the participants.

TEACHER RESPONSE

I hope I can do it again. I hope I can travel internationally with my whole class again. 


\section{REFERENCES}

[1] American Academy of Arts \& Sciences (AMACAD) (2017). America's Languages: Investing in Language Education for the 21st Century. https://www.amacad.org/publication/americas-languages (accessed 17/5/2019).

[2] American Councils on International Education (2017). The National K-12 Foreign Language Enrollment Study Report. https://www.americancouncils.org/news/announcements/new-report-world-language-study-us-k-12-schools (accessed 17/5/2019).

[3] American Elementary School Kids to Meet Their French Video Pals in Paris (2018). https://www.prnewswire.com/newsreleases/american-elementary-school-kids-to-meet-their-french-video-pals-in-paris-300678357.html (accessed 17/5/2019).

[4] Americans for the Arts. https://www.americansforthearts.org/by-program/networks-and-councils/arts-education-network/toolsresources/arts-ed-navigator/facts-figures (accessed 17/5/2019).

[5] Augsburg, T. (2006). Becoming Interdisciplinary $2^{\text {nd }}$ ed. Dubuque, IA: Kendall/Hunt.

[6] Callahan, M. (2017). The Givers: Wealth, Power, and Philanthropy in a New Gilded Age. NY: Knopf.

[7] Clayton, M. (1998). Learn French while Dancing: Students Make the Leap with Panache. https://www.csmonitor.com/1998/0609/060998.feat.feat.5.html (accessed 17/5/2019).

[8] Creswell, J.W., \& Creswell, J.D. (2018). Research Design: Qualitative, Quantitative, and Mixed Methods Approaches $5^{\text {th }}$ ed. Thousand Oaks, CA: Sage.

[9] Eger, J.M (2015). Art Is a Universal Language. https://www.huffpost.com/entry/if-art-is-a-universal-lan_b_806787 (accessed $17 / 5 / 2019)$

[10] Florida, R. (2008). Who's Your City? How the Creative Economy is Making Where You Live the Most Important Decision of your Life. New York: Basic.

[11] Giving USA 2018: Americans Gave $\$ 410.02$ Billion to Charity in 2017, Crossing the $\$ 400$ Billion Mark for the First Time https://givingusa.org/giving-usa-2018-americans-gave-410-02-billion-to-charity-in-2017-crossing-the-400-billion-mark-forthe-first-time/ (accessed 17/5/2019).

[12] Hogenboom, M. (2015). The Traits That Make Human Beings Unique. http://www.bbc.com/future/story/20150706-the-smalllist-of-things-that-make-humans-unique (accessed 17/5/2019).

[13] Kamenetz, A. (2016) 6 Potential Brain Benefits of Bilingual Education. https://www.npr.org/sections/ed/2016/11/29/497943749/6-potential-brain-benefits-of-bilingual-education

[14] Leeming, D. (1998). Amazing Grace: A Life of Beauford Delaney. New York: Oxford.

[15] Les Amis de Beauford Delaney is partnering with the Wells International Foundation (WIF) to take the Beauford Delaney: Resonance of Form and Vibration of Color exhibition to the U.S.! (2017). http://lesamisdebeauforddelaney.blogspot.com/2017/12/beauford-unites-elementary-school.html (accessed 17/5/2019).

[16] Livermore, D. (2016). Driven by Difference: How Great Companies Fuel Innovation through Diversity. New York: AMACOM.

[17] Maslyk, J. (2016). STEAM Makers: Fostering Creativity and Innovation in the Classroom. Thousand Oaks, CA: Corwin.

[18] Merriam-Webster. Philanthropy. https://www.merriam-webster.com/dictionary/philanthropy (accessed 17/5/2019).

[19] Modern Language Association (MLA) (2007). Foreign Languages and Higher Education: New Structures for a Changed World. https://www.mla.org/Resources/Research/Surveys-Reports-and-Other-Documents/Teaching-Enrollments-andPrograms/Foreign-Languages-and-Higher-Education-New-Structures-for-a-Changed-World (accessed 17/5/2019).

[20] Newell, W.H. (2010). Educating for a Complex World: Integrative Learning and Interdisciplinary Studies. https://www.aacu.org/publications-research/periodicals/educating-complex-world-integrative-learning-and-interdisciplinary (accessed 17/5/2019).

[21] Organisation internationale de la Francophonie (OIF). Welcome to the International Organisation of the Francophonie's Official Website. https://www.francophonie.org/welcome-to-the-international.html (accessed 17/5/2019).

[22] Partnership for 21st Century Learning: A Network of Battelle for Kids. http://www.battelleforkids.org/networks/p21 (accessed 17/5/2019).

[23] Quain, S. (2018) What's the Importance of International Education? https://www.american.edu/sis/news/20180306-whats-theimportance-of-international-education.cfm (accessed 18 Jun 2019)

[24] Rickman, C. (2018). Famous Expats Who Made France Their Home. https://frenchly.us/famous-expats-who-made-france-theirhome/ (accessed 17/5/2019).

[25] Smithsonian American Art Museum (SAAM). Beauford Delaney. https://americanart.si.edu/artist/beauford-delaney-1186 (accessed 17/5/2019).

[26] Sousa, D.A. \& Pilecki, T. (2018). From STEM to STEAM: Brain-Compatible Strategies That Integrate the Arts ${ }^{\text {th }}$ ed. Thousand Oaks, CA: STE.

[27] STEAM not STEM: Why scientists need arts training. https://theconversation.com/steam-not-stem-why-scientists-need-artstraining-89788 (accessed 17/5/2019).

[28] Stein-Smith, K. (2018). From Knoxville to Paris: Linking Art and Bilingual Education. https://france-amerique.com/en/fromknoxville-to-paris-linking-art-and-bilingual-education/(accessed 17/5/2019).

[29] STEM to STEAM. http://stemtosteam.org/ (accessed 17/5/2019).

[30] Stevens Garmon, M. (2019). The Delaney Brothers. https://www.mcny.org/story/delaneybrothers?gclid=CjwKCAjwwZrmBRA7EiwA4iMzBALBywKTbOJBsS3tqv_0ikEyJIAV1SiDnHZBSF7Or57VZE3C9QDnhoC8d8QAvD_BwE (accessed 17/5/2019).

[31] Thompson, A. (2016). Learning a New Language Has a Lot of Benefits, Including Making You More Tolerant. https://www.weforum.org/agenda/2016/12/learning-a-language-has-a-lot-of-benefits-including-making-you-more tolerant?utm_content=buffer8d005\&utm_medium=social\&utm_source=facebook.com\&utm_campaign=buffer (accessed 17/5/2019).

[32] Wells International Foundation (WIF). Classes Duo: Knoxville Art Exhibition. https://wellsinternationalfoundation.org/kmaart-exhibition/(accessed 17/5/2019). 
[33] Yin, R.K. (2017). Case Study Research and Applications: Designs and Methods. 6th ed. Thousand Oaks, CA: Sage.

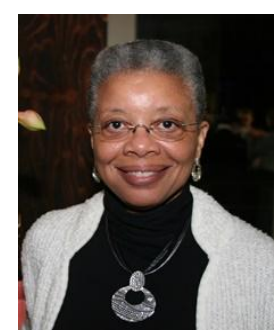

Monique Y. Wells is a board-certified veterinary pathologist and toxicologist from Houston, Texas, USA. She holds a master's degree in veterinary pathobiology from The Ohio State University (Columbus, OH, 1989), a Doctorate in Veterinary Medicine from the University of Pennsylvania (Philadelphia, PA, 1985), and a bachelor's degree from the University of Pennsylvania (biology major, French minor; Philadelphia, PA; 1981).

She is Founder and CEO of the Wells International Foundation, a U.S. 501(c)(3) non-profit organization domiciled in Houston, Texas, whose mission is to empower women and persons of African descent to realize their highest potential through arts, literacy, study abroad, and other educational and cultural programs. She is also President of Toxicology/Pathology Services, a preclinical safety consultancy through which she evaluates preclinical safety data and laboratories producing such data in support of the registration of pharmaceuticals, other chemicals, and medical devices across the globe. She operates both organizations from Paris, France. She is the first author of the book chapter entitled "Evaluating Clinical Pathology Data" in Presenting Toxicology Results: How to Evaluate Data and Write Reports (Nohynek, G.J., editor; Taylor and Francis, London; 1996) and numerous articles in peer-reviewed pathology journals.

Dr. Wells is a Diplomate of the American College of Veterinary Pathologists, the European College of Veterinary Pathologists, and the American Board of Toxicology. She is a member of the Society of Toxicologic Pathology and has served as an Associate Editor of the society's peer-reviewed journal as well as a member of its Continuing Education Committee. Additionally, she is a member of the International Harmonization of Nomenclature and Diagnostic Criteria for Rats and Mice (INHAND): Cardiovascular System Working Group. As Senior Toxicologist and Principal Pathologist, Life Sciences Research for L'Oréal, she represented the company for the L'Oréal-UNESCO Women in Science program - an initiative designed to encourage women to choose science as a career and to recognize the achievements of established woman scientists.

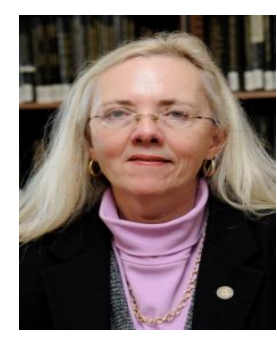

Kathleen Stein-Smith, PhD, Chevalier dans l'Ordre des Palmes académiques, is a dedicated foreign language educator and advocate.

She is Chair of the AATF (American Association of Teachers of French) Commission on Advocacy and a member of the ATA Education and Pedagogy Committee. She is also active in foreign language education associations, including the NECTFL Advisory Council, CSCTFL Advisory Council, and as a SCOLT sponsor.

She has presented at numerous professional conferences at the state, regional, and national level, is the author of four books and numerous articles about the foreign language deficit, has given a TEDx talk on The U.S. foreign language deficit, has been interviewed by press and radio, and maintains a blog, "Language Matters." 